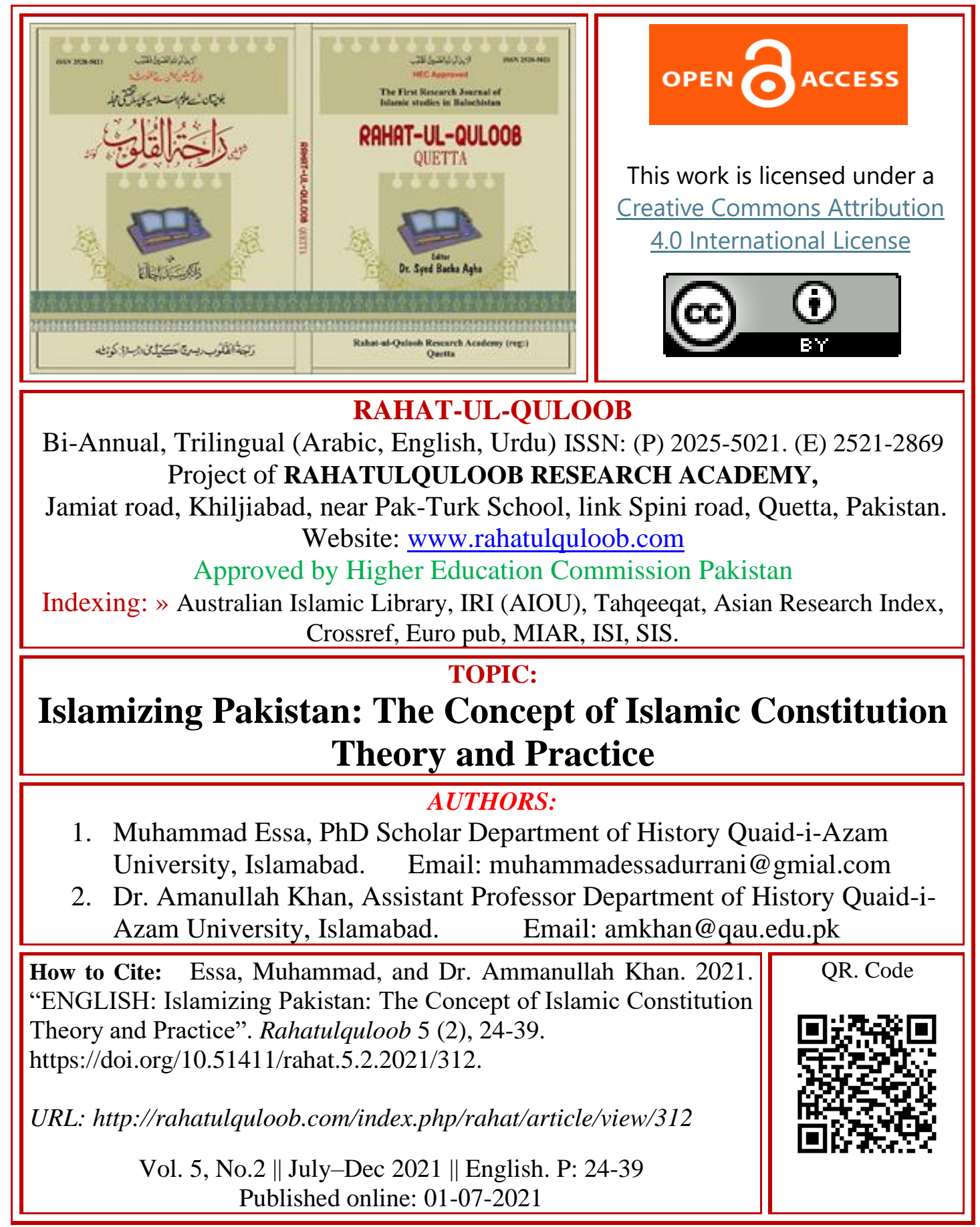




\section{Islamizing Pakistan: The Concept of Islamic Constitution Theory and Practice \\ ${ }^{1}$ Muhammad Essa, ${ }^{2}$ Amanullah Khan}

\section{ABSTRACT:}

The struggle for Pakistan continued till the Muslims of India voted for Muslim League in the elections of 1946 overwhelmingly. After the Third June Plan 1947 it was then clear that India was going to be divided and a new country Pakistan was to be carved out. And ultimately Pakistan emerged as an independent state on August 14, 1947. Pakistan after independence faced many problems ranging from the settlement of refugees to the fragile economy and unsteady defense. One of the major issues was the framing of constitution. Pakistan was a diverse country with two geographically separated wings, different cultures and divergent languages. The Constituent Assembly, which was set up under Indian Independence Act 1947 faced this huge responsibility, to provide a document on which the country could be run.

Keywords: Islamizing Pakistan, Islamic Constitution, Political Parties, Ulama.

\section{Introduction:}

On the question of the future of Muslims in India, during the last decade of British rule, there were different views. All India Congress was the largest party that claimed for Hindu-Muslim identity bound to Hindustan. However; Muslim League argued that Muslims were a different nation and demanded the partition of India. Thus, Muslim League championed the Pakistan Movement and left no stone unturned to canvass support for Pakistan. During the struggle for Pakistan, Muslim population was mobilized on a large scale on the cause of Islam and for that Muhammad Ali Jinnah tried to win over Ulama and Mashaikh. This was the moment when pro- Muslim League Ulama supported the movement of Muslim League on the promise that Pakistan would be an Islamic State. An Important figure Maulana Shabir Ahmed Usmani along with other Ulama, i.e., Mufti Muhammad Shafi, Maulana Ehtisham-ulHaq Thanvi, Maulana Zafar Ahmad Usmani and Mufti Muhammad Hassan ${ }^{1}$ sided with M. A. Jinnah. They were the prominent figures who broke with Jamiat Ulama-iHind (JUH) in 1945 and formed their own political party known as All India Jamiat Ulama-i-Islam (JUI) and supported the slogan of Pakistan. ${ }^{2}$ In a speech to the people of Peshawar on June 29, 1947 Maulana Shabir Ahmed Usmani, the President of JUI said, "Gentlemen!, in Pakistan there will be servility of Allah there will be no dance, incantation and cake and ale because we can only survive in this world due to our virtues and will vanish owing to our own vices." 3

On the other hand, there was another party called as Jamat-i-Islami (JI) that believed in the nationhood of Muslims but was staunchly against the division of India and believed that Muslims were not merely a nation but was a party of single ideology and principle. Therefore, if they struggled for their ideological livelihood instead of national safeguard and interest then not only the threat to their existence could be 
evaded but also it was quite possible that complete Hindustan could have become Dar-ul-Islam. ${ }^{4}$

M.A.Jinnah, the first Governor General and the President of the Constituent Assembly, did not give a clear view on the issue of Constitution and left it to be resolved by the Constituent Assembly as he said in his August 11, 1947 speech; "The Constituent Assembly has got two main functions to perform. The first is very onerous and responsible task of framing our future constitution of Pakistan and the second of functioning as a full and complete sovereign body as the federal legislature of Pakistan." However he provided the guiding principles for the nature of the State of Pakistan in which there would be equality among the citizens of Pakistan as he said, "We are starting in the days when there is no discrimination, no distinction between one community and another, no discrimination one caste or creed and another. We are starting with this fundamental principle that we are all citizens and equal citizens of one state." ${ }^{\prime 6}$ He further argued, "... in course of time Hindus would cease to be Hindus and Muslim would cease to be Muslims, not in the religious sense, because that is the personal faith of each individual, but in the political sense as citizens of the state."7

When the debate on the future constitution of Pakistan began among the political leaders, the Hindu minority wanted a secular constitution and the Muslim League leadership strongly demanded that the constitution should be modernist in its nature for the true Islamic democracy in the country. As they were in majority in the Constituent Assembly, therefore; this notion got ground so Ulama and Jamat-i-Islami felt threatened that Pakistan was not going to be an Islamic country with Islamic constitution according to their point of view.

The two major Islamic parties after the partition were Jamat-i-Islami and Jamiat Ulama-i-Islam (JUI) that struggled for the Islamic Constitution. ${ }^{8}$ The term Islamic Constitution was very vague and general in its nature thus it needed interpretation and explanation. The epistemology of Islamic constitution was obviously Islam and it meant the basis of Islam is the Holy Quran and the Sunnah of the Holy Prophet (PBUH). However, when it came to the meaning of Islamic Constitution in legalistic terms, there existed difference of opinion among various sects based on their respective schools of thought. In this way the basis provided for the Islamic Constitution varied both in theory and practice. This article deals with the theoretical and practical aspects of the Islamic Constitution given by the scholars of Jamat-i-Islami (JI), Jamiat-i-Ulama Islam (JUI) and comparative analysis has been drawn in this regard. ${ }^{9}$ The mechanism of their working was totally different. Jamiat Ulama-i-Islam had its representative in the Constituent Assembly in form of Maulana Shabir Ahmed Usmani but Jamat-i-Islami had no representative in the Assembly. Furthermore, JUI had supported the cause of Pakistan and was in the good books of Muslim League and Usmani had intimate relations with Jinnah, however; Maududi was an influential Islamic scholar but had not direct links with the government. In this way JUI used its influence in the power corridors without any public pressure while JI had no option 
other than taking the subject of Islamic constitution to public and pressurizing the government through protests and large public assemblies.

\section{Theoretical Debate}

The theoretical debate on Islamic Constitution by both JUI and JI is complex in nature, therefore; there is no common ground where it could be reconciled in a single pattern. In order to provide basis for the Islamic Constitution, the religio-political parties not only provide sources from the Quran, Hadith and Sunnah but also place the sources from ancestral theological manuscripts and then come down to the big names of their respective schools such as Deobandis refer to the scholars of Deoband and the followers of Jamat-i-Islami endorse the ideology of Maulana Maududi.

The basic text on which all sects agree in philosophical terms is the Holy Quran while they differ on its interpretation. ${ }^{10}$ Maulana Maududi the founder of Jamat-i-Islami has provided ten-point agenda taken from Quran and has claimed that it should be the basis of Islamic Constitution, ${ }^{11}$ similarly Mufti Taqi Usmani a Deobandi scholar, ${ }^{12}$ has presented nineteen points from the Quran and has argued that Islamic Constitution cannot be devoid of the said postulates. ${ }^{13}$

The first Principle which both the parties agree is the Sovereignty of Allah. In this they refer to the Quranic verse "Sovereignty belongs to none but Allah."14 In the long interpretation, Maulana Maududi has used the word Sovereignty, and in the commentary, he has used the context of Surah Yusuf in which Prophet Yusuf while explaining the meaning of the dreams of the two prisoners preaches to them and says that $H u k m$ Belongs to none but Allah. By that, Maududi meant in his Tafhim-ul-Quran, "He has sent no authority and given no sanction to anyone for Godhead and worship, but has reserved all the powers, all the rights and all the authorities for Himself, and commanded, 'Serve and worship none but Me." ${ }^{15}$ However, in the interpretation of the same verse in his paper Islami Dastoor ki Bunyaden (the foundations of Islamic Constitution) included in the book Islami Riyasat, ${ }^{16}$ he has not mentioned any context of the verse (though he has put the Surah reference) and has pointed out that in this verse there is no such word or standard on the basis of which this Lordship can be restricted to the meaning of just "Universal Sovereignty". The way this rule is universal, similarly; it is political, constitutional, moral and etiqadi (part of belief). ${ }^{17}$ Therefore; it means that while interpreting the Quranic Verse in Tafhim-ul-Quran he had no objective of explaining or presenting the structure for Islamic Constitution thus did not explain the said verse in detail but in writing the paper for Islamic Constitution he has interpreted the verse without any context and in much detail. In this way it can be concluded that for Maududi the wording and translation of the Quran will remain same but the meaning of the interpretation can vary according to the objective.

Mufti Taqi Usmani has used the word Hakimiyat i.e. The Rule belongs to no one except Allah ${ }^{18}$ while Shabir Ahmed Usmani has used the word Government. ${ }^{19}$ Both of them have not given any interpretation to the said verse in their commentaries of Quran however, Taqi Usmani in his book, Nifaz-i-Shariat, has argued that this is the 
postulate that differentiates the Islamic Constitution from secular democracies. In secular democracy, sovereignty belongs to people who can decide against the will of God; however, in Islam the actual right to rule belongs to Allah. ${ }^{20}$ Taqi Usmani has also not provided any context to the verse and has treated it independently.

The Second principle which Maududi suggested was the status of the Prophethood ${ }^{21}$ as in the Quran, "But no, by thy Lord! They will not believe till they make thee the judge regarding the disagreement between them, then they shall find in themselves no impediment touching thy verdict, but shall surrender in full submission." $(4: 65)^{22}$. Mufti Muhammad Shafi has given a bit different summary of the interpretation to this verse "By thy Lord O Prophet (PBUH) these people (who just manifest verbal faith to God), will not be believers till then when they have a dispute, they accept your judgment [if you (PBUH) are not present then from Your Sharia] and [when the Prophet (PBUH) award a judgment then) from Your (PBUH) judgment do not feel heartache (with negation) and accept it (the judgment) wholly (both overtly and covertly). Ahmed Reza Khan Brelvi giving the interpretation of the same verse has provided the background ${ }^{23}$ while Maududi, Taqi Usmani and Shafi Usmani have not given any specific backdrop of the verse and they all agree on the point that Prophet (PBUH) should be the final arbiter because "Whoso Obeys the Messenger, obeys Allah". (4:80) Therefore it is the second source of sovereignty which must be obeyed. ${ }^{24}$

Usmani's second postulate is that no law should be and no executive order can be passed against Quran and Sunnah, nor will it sustain. "Whoso judges not according to what God has sent down----they are the unbelievers". $(5: 44)^{26}$ by quoting this verse from the Quran, according to Taqi Usmani, the decisions taken in an Islamic State should be according to the Islamic Constitution and those who do not decide according Quran and Sunnah are not Muslims but they (Usmani) and Maududi have not provided any interpretation to the same verse in their commentaries,${ }^{27}$ however; Shabir Ahmed Usmani has pointed out that here in this verse there may be two conditions the first one is those who do not believe in it as a doctrine are verily non-believers but those who believe in it but do not act accordingly resemble with non-believers in their actions. ${ }^{28}$ Mufti Shafi also has the same view about this verse, however; presented a different aspect that those who deliberately present a non-sharie judgment as a sharie judgment are absolutely non-believers. ${ }^{29}$ While Ahmed Reza Khan Brelvi has presented only one condition i.e. if they deny. ${ }^{30}$ In this way the second postulate of Usmani about the Islamic constitution carry ambiguity in the sense that it gives the impression that those who legislate and decide against the Quranic laws, which need interpretation and there is no single interpretation on which there is complete agreement, are all non-believers. Thus, by his definition without any delicacy all judges and parliamentarians might be non-Muslims because he has not presented any specifications and detail while presenting the basic postulates of Islamic Constitution. The third point for Maududi is the concept of Khilafat as the Quran says, "God has promised those of you who believe and do righteous deeds that He will surely make 
you successors in the land, even as He made those who were before them successors." $(24: 55) .{ }^{31}$ This verse reflects upon two fundamental points, according to Maududi, the first one is; the actual status of the Islamic state is "Khilafat" not government and secondly in Islamic State Khilafat does not belong to a man, a family or a class rather it is comprised of the complete Islamic Ummah to whom Allah has bestowed an independent state. ${ }^{32}$ Therefore, from Islamic point of view, human being is the vicegerent of God on earth i.e., he uses the given authority in his (God's) estate. Thus, against the concept of "Popular Sovereignty" Islam has given the conception of "Popular Viceregency". ${ }^{33}$ In this way there are basically four conditions in which humans should work as deputy to God. Firstly he should keep in mind that the real owner of the estate is God, secondly one should work according to the given instructions, thirdly humans have to work for God's interest and fourthly the former has to work within the limits prescribed by the later. ${ }^{34}$ In this way an Islamic state works under the sovereignty of God and under the Viceregency of Humans. ${ }^{35}$ However, there is a condition that the promise which God has made of giving Khilafat does not include Muslims of census rather those Muslims who are truthful in their faith, righteous in their morality.... and are devoid of any shirk. ${ }^{36}$ Taqi Usmain, Shabbir Ahmed Usmani, Mufti Shafi and Ahmed Reza Khan Barelvi share the same view about the concept of Khilafat and the promise made by Allah to grant Khilafat to Muslims in the earth. At the same time, Taqi Usmani has added another verse to the Khilafat that "I am going to appoint a viceregent" (2:30) and has seconded the point of Maududi that humans have no right to decide against the precept of Allah. ${ }^{37}$

The third point according to Taqi Usmani and Maududi's seventh point is the objective of the government, "who, if We establish them in the land, perform the prayer, and pay the alms, and bid to honour and forbid dishonor;" 38 In the light of this verse, all Ulama agree that it verily cannot be called as an Islamic government that does not care about the establishment of prayer and payment of zakat. It does not take in to account the spread of vices in which adultery, drinking, gambling, obscene literature, indecent films... are present and there is no hindrance on these things. Thus, in an Islamic Constitution, it should be a state's basic objective to stop all these frailties. ${ }^{39}$ The purpose of a state in Islam is neither merely an administrative one nor subject to the collective desires of a specific class rather Islam sets a high standard i.e., God wants purity, progress and welfare of human beings, for which the state should utilize its all resources. ${ }^{40}$ The fourth postulate is the "Consultation" as in Quran "they manage their affairs by mutual consultation" (42:38) Consultation is the core of Islamic government. Islamic government is the first institution that put an end to kingship, issued the principle of public opinion and handed over the government to the elected imam (chief executive). ${ }^{41}$ Maududi argues that Islam has not provided any specific pattern of the shura (consultative body) which can be set up by the people according to their norms and traditions and this may vary in different times. ${ }^{42}$ He has provided three basic principles for the shura that, 
1. The collective work of Muslims shall never be carried out without consultation. The ruler cannot impose himself. Thus, this puts an end to dictatorship.

2. All those shall be consulted who are involved in a collective work whether directly or indirectly.

3. Consultation shall be free from any pressure or incentive. ${ }^{43}$

However; there is an important point that this consultative body is not independent and is restricted by the contours of religion. Muslims can have consultation on matters of sharia but cannot confab on which Allah and His Prophet (PBUH) have already decided. ${ }^{44}$ Shafi Usmani, in the commentary of the above mentioned verse has put an Hadith that once the Prophet (PBUH) was asked by Ali (R.A) that if we are confronted by a situation in which there Quran has not decided anything and you have also not given any instruction what should we do, the Prophet (PBUH) said "for that assemble the obedient from my Ummah and place the matter for consultation. Do not make decision on the basis of the opinion of any single person". ${ }^{45}$ In it the word Abdeen/Abid has been used which is referring to those who are well versed in Din and are good worshipers. Thus, it means that Fuqaha (jurists) should be consulted. ${ }^{46}$ But Maududi differs on the point that it means those people who worship God and do not adopt the rebellious attitude. ${ }^{47}$ Therefore, all agree that the government formed should be of consultation but they differ on the mechanism of consultation. They all argue that Islam has propounded the concept of democracy but for Maududi under the theory of popular viceregency, which means all are equal in viceregency; only those shall be consulted who are good Muslims and for Shafi they are the jurists. Thus, in legalistic terms all of them disagree with their own arguments of democracy as for the shura a common man does not qualify. Furthermore; there is no clarification or definition of jurists and good Muslims. Neither there are any qualifications detailed down by any scholar by virtue of which, they could agree on a single definition or qualification.

The next point is the Election Principle. As in Quran, "God commands you to deliver trusts back to their owners." $" 48$ (4:58) For Maududi it means that there shall be an amir to whom the responsibility of administration will be assigned. He will be considered as the president of the republic. In elections all those adult male and female shall have the right to vote who accept the constitution. ${ }^{49}$ An amir can be elected if he has acquaintance with the spirit of Islam, has Islamic character, fears God, patient and has the support of the majority of the people in a society. ${ }^{50}$ Mufti Shafi, Allama Shabbir Ahmed Usmani and Ahmed Reza Khan Brelvi have a similar point of view regarding the background of the verse. They argue that it was revealed when the Prophet (PBUH) conquered Makkah and took the keys of Ka'aba from Usman Bin Talha, the incharge of the gates of Ka'aba, who once had refused to hand over the keys of Makkah to the Prophet (PBUH) and the Prophet (PBUH) had said that O Usman! May be one day you will see these keys in my hands and I will have the authority to hand over it to any one whom I would want, ${ }^{51}$ and went in to Ka'aba and when the Prophet came out, he was reciting this verse and handed over the keys back to Usman. This 
verse nevertheless, in general, means that all the governmental positions are a trust and it should be handed over to those who are qualified for that. Furthermore, Maududi has also argued that this verse refers to the vices that were prevalent in BaniIsrael. One of their basic errors was that they elected or handed over their positions of trust to those who were incompetent, immoral and untrusted. ${ }^{52}$

The next principle of the Islamic Constitution is the "Head of the State". As in the Quran, "O believers, obey God, and obey the Messenger and those in authority among you. If you should quarrel on anything, refer it to God and the Messenger, if you believe in God and the Last Day; that is better and fairer in the issue." ${ }^{53}$ This verse explains the following points according to Maududi. Firstly, Obedience to God and to His Messenger is the actual obeisance. Secondly obeying those in authority is secondary in nature; thirdly this secondary obedience is subservient and dependent on the former ${ }^{54}$ and fourthly in an Islamic system God's commandment and the Sunnah of the prophet (PBUH) are the final authority. Therefore, in an any dispute, the decision shall be referred to Quran and Sunnah. However, if there is no explanation present in the mentioned sources, Mufti Muhammad Shafi writes, then they are free in limits to legislate on such matters. ${ }^{55}$ Explaining the word "Oolil-Amr", Maududi, Brelvi, Usmani state that, they should be among Muslims, and it includes all those who are the leaders in the collective affairs of Muslims whether they are Ulama, political representatives, Government servants, judges or chieftains ${ }^{56}$ but Mufti Shafi has pointed only two categories i.e. the government and the Ulama; ${ }^{57}$ while they all agree that they should be followed till they are on the right path. One thing which is prominently featured is that the ruler in all terms should be a Muslim thus a non-Muslim cannot become the head of an Islamic state. Another point of the Islamic Constitution is the Fundamental Rights and Independence of Judiciary. As in the Quran,

1. "And slay not the soul God has forbidden, except by right" 58 (17:33), in this it is clearly written that killing anybody is forbidden in Islam. Therefore, it becomes the basic human right that a government should take such measures in which killing should be stopped. However, the Islamic law has authorized the killing, "for right", for Maududi, in five conditions and for Mufti Shafi, in three conditions i.e., the one who killed anyone secondly involved in adultery despite being married and thirdly who renounced Islam. ${ }^{59}$ The other two conditions propounded by Maududi are the opponents of the true religion during war and who attempt to overthrow the Islamic system of government. ${ }^{60}$

2. The second basic human right is the right to property as Quran says, "Do not usurp one another's property by unjust means" (2:188), this verse has put a rule that it is obligatory that Muslims should not claim the property of someone else unjustly. If someone does claim it and wins it in a court of law, still in the court of God it is forbidden and actually (by doing this) "you have won a piece of fire from hell". ${ }^{61}$

3. Another fundamental right is "O believers, let not any people scoff at another people..."62 (49:11), on the basis of this verse and the later verses, Maududi argues 
that in an Islamic constitution, the law of Libel can be formulated. Allah in this verse has stated that "the believers were made realize that by virtue of the most sacred relationship of the faith they were brothers one to another, and they should fear God and try to keep their mutual relations right." ${ }^{" 63}$ While Shabir Ahmed Usmani states that God Almighty has forbidden that a Party should neither mock at each other, nor search for stigmas in each other because that would lead to enmity and hatred. ${ }^{64}$

4. "There is no compulsion and coercion in regard to religion" $(2: 256)$, it's another right of the citizens of the state that the religion of Islam shall not be imposed on any nonMuslim subject, however; once anyone who accepts Islam shall not be allowed to renounce it. Because there is no reason for one not to accept the reality once he faces it. ${ }^{65}$ Shabir Usmani explained it in other words that if the logic of religion is explained to someone and he has no doubt in it then one should not force someone to accept Islam however; who accepts to pay Jizya, his life and property would be safe. ${ }^{66}$

5. "Teach them the Book and Wisdom" $(2: 129)$ it should be the duty of the government to make arrangements in which the Book of God and Hikma ${ }^{67}$ shall be taught.

6. The independence of judiciary, "the enmity of any people should not so provoke you as to turn you away from justice. Do justice for it is akin to piety" $(5: 8)$, this verse has pointed towards the individual and collective justice but for an Islamic state it is necessary to do justice in its all forms. The judiciary therefore shall not be under any pressure from any corner. In another verse, "judge between the people by the Law sent down by Allah and do not follow their desires" (5:48), this verse indicates to another aspect of the judiciary that decide according the law sent by Allah by it both Maududi and Shafi agree that it means Sharia.

7. As for the Status of women in an Islamic Constitution, Maududi has referred to the Quranic Verse. "Men are the guardians of women". By this verse Maududi claims that the managerial affairs should be in the hands of man as he is the "protector and, manager of the affairs of women." 68 Therefore; women cannot be entrusted with the authority to rule or make policies for a state as their place is in the household. ${ }^{69}$ Both Shabbir Ahmed Usmani and Shafi Usmani hold the same view about the status of women.

8. About the position of minorities in the constitution all the Islamic parties and scholars hold a similar view that once the "God's Government" is established then it is not a government of a nation or a party rather it is a government that is established on the principles ordained by God himself. Therefore; in this way, that type of government could be run only by those who believe in those principles. By presenting this logic Maududi and Shabbir Ahmed Usmani conclude that all non-Muslims could live in an Islamic state on equal footings with all other Muslim citizens but they cannot be the part of policy making.

\section{Political Behavior}

This was the theoretical debate based on the comparative study of the Quran while in practice for the first time after partition; Maududi explained the nature of an Islamic State and Constitution in his speeches at Law College Lahore on January 6, 1948 and 
February 19, 1948. In those speeches he presented a formula as he articulated, "The source of Islam, a way of life, is a book.....and the last edition is presented before humanity in form of the Holy Quran."70 In its support he further argued, "The ideology of life which is presented by this book and the prophet (PBUH) is that this great universe which is superficially compact, interwoven and seems running on an established principle is actually the rule of a God. God is it's the creator; he is the owner and the suzerain." 71 Therefore; "those who surrender their independence to God voluntarily, this act is called as Islam, and those who do this are called as Muslim"72. Thus, "This will give rise to a "Muslim Society". It is administered through a contract that comes between God and humans consciously. In this contract the subjects accept that God is their ruler, his guidance is the make-up of their life, his commandments are laws for them, they will accept anything as good what God tells them what is good and will assume the evil to which God will confer as evil.... After this overt confession when a society is formed then the Al-Kitab (The Book) and AlRasul (The Prophet) provide them with a way of life which is called as Shariat."73 About Shariat he said, "it is a single map of life. It has a collective nature and cannot stand partitioned. Its unity is similar to that of the existence of human himself. ${ }^{74}$ Islam is the name of that complete code not of its separate parts. ${ }^{75}$ " In this speech Maududi after explaining the different aspect of Sharia started to shed light upon the last part of Sharia i.e., its political aspect and reiterated, "The last and major part of Sharia demands the establishment of a political authority in a Muslim Society as it cannot be implemented without the rule. This political suzerainty is aimed at the protection of the proposed lifestyle of Sharia. It is needed to safeguard this lifestyle from mutation and for propagation of good and impeding the evil according to its wishes and for that a separate judicial system is necessary."76 Shariat, according to Maududi have two main sections the first section is settled while the second part is open "In this law the adjudicated part is consisted of three parts, one; the clear commandments, two; principled orders, three; Hudood"77 The other part of Shariat is extended composed of Tabeer, Qiyas, Ijtehad and Istehsan. This section widens the scope of Islamic Law. ${ }^{78}$ In the other speech on February 19, 1948, Maududi explained the practical mechanism of implementation of the theory presented by him. The basic requirement for the establishment of an Islamic State was an Islamic revolution through evolutionary process. The foundations of the nascent state, according to Maududi, had to be Islamized and for that the Constituent Assembly should formally announce that;

1. That the Sovereignty in Pakistan belongs to God Almighty alone and that the Government of Pakistan shall administer the country as His agent.

2. That the Basic law of the land is the Islamic Sharia which has come to us through our Prophet Muhammad (PBUH)

3. That all those existing laws which may be in conflict with the Sharia shall in due course be repealed or brought in to conformity with the basic law and no law which may be in any way repugnant to Shariah shall be enacted in future. 
4. That the state, in exercising its powers, shall not be competent to transgress the limits laid down by Islam. ${ }^{79}$

Maududi declared these four points are the verses for the state to recite it through its Constituent Assembly through which it would become Muslim. ${ }^{80}$ The second step was that the reigns of the government should be handed over to those who not only know Islam but also want to mould the system of state according to it. ${ }^{81}$ After these basic points, in order to pressurize the government Jamat-i-Islami held public meetings throughout the country and in his speeches, Maududi emphasized that objective of achieving Pakistan was establishing an Islamic state so the people in authority should keep their promises and make Pakistan an Islamic state by drafting and implementing the Islamic Constitution.

On the other hand, Maulana Shabir Ahmed Usmani who was a close friend of Jinnah also demanded the Islamic Constitution in his Presidential address of Dhaka Conference in February 1949. He said, "no matter how we are treated by the people in authority... we can never relinquish the efforts for an Islamic Constitution and the system of government through which it can be ensured that Muslim nation can fulfill its individual and collective necessities in accordance with the Islamic injunctions which is testified from Quran and Sunnah." 82 While discussing the difficulties how Pakistan was achieved he further said, "Praise be to God, they got such a piece of land where Muslims have the power and authority if they want to establish Islamic law and Constitution, no power in the world can deter them." 83 For this purpose he presented his 9 points; and explained that that "our, the largest Islamic, Country should keep in mind the objectives and basic principles which according to us should be as follows;

1. To establish peace and justice for the citizens of Pakistan without the discrimination of religion, race and nationality and inviting other nations towards this objective.

2. To honor the treaties signed with other countries.

3. To run the affairs of the state with belief in Allah Almighty as the owner, true and real master of this whole country, as deputy in trust, in the limits prescribed by him with the conscience of complete accountability.

4. To make efforts binding the Muslim Nation on the divine law that is revealed by the Lord for their benefit along with the handling of protection of the life, property, religious freedom and rights of citizenship of the non-Muslim population along with the safeguard of Islam.

5. By encouraging the individual monetary capabilities of the subjects of Pakistan keeping a proper and moderate balance in their economic condition and do not devoid any one from the needs of life to the extent possible.

6. To impede the social nastiness to the extent possible such as usury, drugs and gambling.

7. Along with the building the high vision, try to make the national society simple and clean.

8. Providing swift and cheap justice to public by taking them out from the western style 
judicial maze.

9. Providing religious and military training to each Pakistani by making them the Mujahid of Islam and the soldier of Pakistan in order to achieve these virtuous and visionary Objectives. ${ }^{84}$

10. They only way to implement this point was as he said, "the Constituent Assembly should setup a committee consisting of eminent Ulama and thinkers to prepare a draft and present it to the Assembly". ${ }^{85}$

\section{Analysis}

By comparing the demands of both Jamat-i-Islami and Jamiat Ulama Islam, it becomes clear that the core demands were somehow similar and the very first objective was to make the leaders of Pakistan compel to accept the sovereignty of Allah. This basic point was very important for both the religio-political parties because if once they succeeded in getting this approved from the assembly, then it meant that the Constituent Assembly was powerless in matters of drafting the constitution as the "limits prescribed by Allah" would have to be kept in mind on each step. This resultantly would yield two outcomes, first; Pakistan could never become a secular state and secondly the religious class along with religio political parties could have greater say and pressure as they were the ones who could better explain what was meant by "Quran and Sunnah".

From the above discussion few common conclusions can be drawn that remained identical in the explanation of the concept of an Islamic Constitution for an Islamic State both by Jamiat Ulama-i-Islam and Jamat-i-Islami. The first one which ground on the above discussion is that an Islamic State should be an ideological state and its constitution should only be based on the ideology of Islam. This means that an Islamic Constitution would negate secularism, any kind of nationalism and subnationalism whether that is territorial, lingual, tribal, or of any other sort. In extreme cases this notion would also forfeit federalism and would prefer centralization of authority. Thus, a unitary system in the state would suit the most to the Islamic constitution. The second ratiocination that appear from the aforementioned arguments is that the sources of an Islamic Constitution should be Quran and Sunnah. This line yields the notion that in an Islamic State whatever is presented or adopted in a legislative assembly should be adjusted to Islam otherwise anything contrary to Islamic Ideology would be unacceptable in an Islamic State. In addition to it, it would always generate the controversies or discussion on the interpretation of the Quran and Sunnah that would finally lead to the establishment of a body in its kind that would have the decision-making power in finalizing the Quranic interpretation.

The third conclusion that can be derived is that an Islamic constitution would be democratic in nature but in it the will of the people would be subservient to the will of God. There would be certain matters that would be pre-decided and that could not be changed however; the matters left over by the Quran and Sunnah could be debated and legislation could be carried out on those subjects. Certainly, this aspect would 
restrict the scope of the parliament and would compromise its supremacy which in secular democracy is considered as the prime institution. Lastly the formulation of the Islamic Constitution would give greater space to the religious section of the society. In modern times, the subject of religion is specialized by Ulama and the religiopolitical parties therefore; in an Islamic State under the Islamic Constitution all the secular parties would be non-existent or less tolerated.

\section{References:}

${ }^{1}$ All of them were the prominent scholars of Dar-ul-Uloom Deoband and had large following among the sunni-deobandi sect. Maulana Shabir Ahmed Usmani was born on October 11, 1887. He was educated at Dar-ul-Uloom Deoband and Joined JUH. Later on, he started supporting Pakistan Movement and became the first President of JUI.

2 Muhammad Abubakr Sheikh, ed. Jamiat Ulama Islam: Taaruf, Tarikh aur Khidmat (Lahore: Makaba-i-Qasimyah, 2013), 4

${ }^{3}$ Abu Hamza Qasmi, Khutbat wa Maktubat-i-Usmani (Lahore: Dar-ul-Shaoor, 1999), 83.

${ }^{4}$ Maulana Sayed Abul-A'ala Maududi, Jamat Islami ka Maqsad, Tarikh aur Laiha Amal (Mansoorah: Islamic Publications Limited, 2014), 25.

${ }^{5}$ Government of Pakistan, Constituent Assembly of Pakistan Debates Official Report Vol 1 10th August to 14th August 1947, Vol. 1, (Karachi: Constituent Assembly of Pakistan, 1947), 18.

${ }^{6}$ Ibid., 20.

${ }^{7}$ Ibid.

8 However, there was another party Jamiat Ulama-i-Pakisan that also played important role in Islamizing the constitution of Pakistan, but it was formed in 1948. However, the scope of this article is limited to only JUI and JI.

${ }^{9}$ It is an interesting fact that in Pakistan different religious sects have their seminaries, political parties and preaching organizations. Such as Brelvi school of thought has its Tanzim-ul-Madaris (organization of seminaries), Dawat-i-Islami (Islamic Preaching) Jamat-i-Ulama Pakista (JUP), Deobandi School of thought has its own Wifaq-ul-Madaris (Federation of Seminaries), Tablighi Jamat (Preaching party) and Jamiat-i-Ulama Islam (Political Party). However, Jamat-i-Islami is not considered as different sect but within Jamat, Jama'at-i-Islami is considered that it is not a merely political, religious or reformist party rather in broader sense it is an ideological party which believes in the universal livelihood theory of Islam for the human life and it has its own Dawah, madaris and has political agenda. Jama'at-iIslami, Manshur Jama-at-i-Islami Pakistan: Umeed Awam Ki, Tabdeeli Nizam Ki. Lahore: Shauba Taluqat-i-Ama, 2011, 8.

I have selected these two political parties for my study because 1) it represent the Sunni deobandi School of thought in broader perspective 2) these political parties remained active in national and provincial politics and even formed governments in different alliances 3) they were mainly the representatives of these parties who raised their voices for Islamic Constitution in early phase and for Islamization in later stages. (Though there were some others too).

10 There are other sources also such as Sunnah and Hadith, the First four Rightly Guided Caliphate, the four Sunni Scholars of Jurisprudence, the Ijma and Ijtehad on which they agree in philosophical terms and disagree in legalistic terms but due the length of study it cannot be included in the present discussion and only Quran will be the center of the current discourse.

${ }^{11}$ Syed Abul'ala Maududi, Islami Riyasat (Lahore: Islamic Publications, 2006), 384.

12 Taqi Usmani, Nifaz-i-Shariat, 10. Muhammad Taqi Usmani has served as a judge of federal Shariat Court and is the vice-president of the DarulUlum madrassa of Karachi which was founded by Mufti M. Shafi who worked for the purpose of Islamic Constitution and was among the top leaders of JUI. 
13 All these foundations provided by the different sects/parties were in response to the demand of Islamic Constitution and a reply to the secular parties which believed in the separation of religion and politics.

${ }^{14}$ Syed Abul'ala Maududi, Tafhim-ul-Quran Vol. 2 (Lahore: Idara Tarjuman-ul-Quran, 2011) 14.

15 Ibid., 40.

16 Syed Abul'ala Maududi, Islami Riyasat, Ibid.

${ }^{17}$ Maududi, Islami Riyasat, 388.

18 Mufti Muhammad Taqi Usmani, Asaan Tarjuma Quran: Tashrihat $k$ Sath (Karachi: Maktaba Muarif-ul-Quran, 2010), 510.

19 Maulana Mehmood-ul-Hasan, Maulana Shabbir Ahmed Usmani and Maulana Muhammad Wali Razi, trans., ed., Tafseer-i-Usmani, 965. http:/www.noorehidayat.orgquran@noorehidayat.org.

${ }^{20}$ Taqi Usmani, Nifaz-i-Shariat, 10.

${ }^{21}$ Syed Abul'ala Maududi, The Islamic Law and Constitution, ed. Khurshid Ahmed (Lahore: Islamic Publications Limited1960), 256.

${ }^{22}$ M. A. S. Abdel Haleem, The Quran (New York: Oxford University Press, 2005), 57.

${ }^{23}$ The background which he has provided is that "there occurred a dispute among a Helper and Hazrat Zubair (May Allah be Pleased with him) on water which came from a mountain to the garden. This issue was taken to the Holy Prophet (PBUH) the Prophet said, O Zubair by watering your garden and then leaving the water towards your neighbor was not liked by the Helper. The Helper uttered the following words that Zubair is the cousin of the Prophet (PBUH). Despite of the Fact that, in the decision, the Prophet (PBUH) had instructed Zubair to grant concession to the Helper but the later did not gave weightage to the decision then the Prophet ordered Zubair to water his garden and stop the water. Objectively the nearest deserves the water on this occasion this verse was revealed. Ahmed Raza Khan Brelvi, Kinz-ul-Iman: 129. https://archive.org/search.php?query=Ahmed\%20Raza\%20Khan

24 Malik Mehboob-ur-Rasool Qadri, Tameer-i-Millat K Liye Jamiat Ulama-i-Pakistan ki Siyasi Jadojehd (Jauharabad: International Ghausia Forum, 2012), 83.

25 Taqi Usmani, Nifaz-i-Shariat, 10.

26 Abdel Haleem, The Quran, 72.

${ }^{27}$ However, later on, in the next verse "those who do not judge by the law which Allah has sent down are indeed the unjust people" (Zalimoon), Usmani has given the long interpretation against the backdrop of a dispute between the two clans of Madina Banu Nazeer and Banu Quraiza who did not decide according to Torah (Taurait).

${ }^{28}$ Usmani, Tafseer-i-Usmani, 462-63.

${ }^{29}$ Mufti Muhammad Shafi, Muarif-ul-Quran Vol. 3 Chapter 5 Verse 44 (Karachi: Maktaba-i-Muariful-Quran, 2008), 156.

${ }^{30}$ Ahmed Raza Khan, Kinz-ul-Iman, 167.

${ }^{31}$ Abdel Haleem, The Quran, 224.

${ }^{32}$ Maududi, Islami Riyasat, 393.

${ }^{33}$ Ibid., 394.

34 Abul'ala Maududi, "Islam ka Siyasi Nizam”, speech on Radio Pakistan Lahore, January 20, 1948 Sarwat Solat, ed. Maulana Maududi ki Taqarir, Vol.1, Lahore: Islamic Publications Limited, 1979, 292 35 Ibid., 293.

36 Syed Abul'ala Maududi, Tafhim-ul-Quran Vol. 3, (Lahore: Idara-i-Tarjuman-ul-Quran, 2011), 417. Explaining the usage of word "Khilaft" Maududi is of the view that "word Khilafat has been used here for the government which discharges the responsibilities of Allah's Vicegerency strictly in accordance with Allah's Law, and not in accordance with mere physical laws of the world. That is why, not to speak of the disbelievers, even the hypocrites, who professed faith in Islam, are being excluded from 
the purview of Allah's promise. That is why it is being stated that true and righteous believers only are worthy of this promise. That is why it is being averred that the establishment of Khilafat will result in the establishment of Islam, Allah's approved religion, on strong foundations; and that is why the condition being put forward for earning this favor is that the believers should remain steadfast in their faith and devotion to Allah avoiding every tinge of shirk. To remove this promise from its right context and apply it on the international scene to the case of America and Russia, or any other power that be, is sheer absurdity and nonsense.

${ }^{37}$ Taqi Usmani, Nifaz-i-Shariat, 10.

${ }^{38}$ Abdel Haleem, The Quran, 212. This verse was revealed on the pretext of the Muslims who migrated from Mecca to Medina and Allah promised them when He will give them the power and they will establish the Din of God on earth. Mufti Shafi Usmani Mufti Taqi Usmani and Allam Shabir Usmani have argued that it is the testimony of the legitimacy of the Khilafat of the Rightly guided Caliphate. However; Maududi has not mentioned the example of first four Caliphs.

${ }^{39}$ Maududi, Islami Riyasat,403-05.

40 Abul'ala Maududi, "Islam ka Siyasi Nizam", speech on Radio Pakistan Lahore, January 20, 1948 in Sarwat Solat, ed. Maulana Maududi ki Taqarir, Vol.1, 294.

${ }^{41}$ Speech of Shabir Ahmed Usmani in the Constituent Assembly on March 9, 1949 for details see Abu Hamza Qasmi, Khutbat-o-Maktubat-i-Usmani (Lahore: Dar-ul-Shaoor, 1999), 143.

${ }^{42}$ Maududi, Islami Riyasat, 396-98.

${ }^{43}$ Ibid.

${ }^{44}$ Maududi, Tafhim-ul-Quran Vol. 4, 510.

${ }^{45}$ Shafi Usmani, Muarif-ul-Quran, Vol. 7, 704.

${ }^{46}$ Ibid.

${ }^{47}$ Maududi, Islami Riyasat, 398.

${ }^{48}$ Abdel Haleem, The Quran, 56.

${ }^{49}$ Sarwat Saulat, Maududi ki Taqarir, Vol.1, 296.

${ }^{50}$ Ibid., 297.

${ }^{51}$ Shafi Usmani, Muarif-ul-Quran, Vol 2, 444. Shabbir Usmani, Tafseer-i-Usmani, 352. Brelvi, Kinzul-Iman, 127.

${ }^{52}$ Maududi, Tafhim-ul-Quran, Vol 1, 362.

${ }^{53}$ Oxford, The Koran, 81.

${ }^{54}$ Maududi, Islami Riyasat, 405.

${ }^{55}$ Tafhim-ul-Quran, Vol 1, 365.

56 Ibid., 364.

${ }^{57}$ Shafi Usmani, Muarif-ul-Quran, Vol 2, 452.

${ }^{58}$ Abdel Haleem, The Quran, 177.

${ }^{59}$ Shafi Usmani. Muarif-ul-Quran, Vol. 5, 477.

${ }^{60}$ Maududi, Tafhim-ul-Quran, Vol. 2, 614.

${ }^{61}$ Maududi, Tafhim-ul-Quran, Vol. 1, 148.

${ }^{62}$ Abdel Haleem, The Quran, 339.

${ }^{63}$ Maududi, Tafhim-ul-Quran, Vol. 5, 84. In this verse Maududi has also criticized the law of libel in the west that those laws are too weak to protect the honor of an individual. However, Islamic law bends upon the protection of the honor of each individual. It is a crime of conviction to humiliate someone on the condition if acceptable evidence is produced.

${ }^{64}$ Shabbir Usmani, Tafseer-i-Usmani, 2093.

${ }^{65}$ Ahmed Raza Khan, Kinz-ul-Iman, 63.

${ }^{66}$ Shabbir Usmani, Tafseer-i-Usmani, 158. 
${ }^{67}$ The word Hikma has different meanings, to reach to truth, Justice, knowledge etc. When this word is used for Allah then it means the "Knowing" and "Perfect Inventions" however; when it is used for other than Allah, it means the existential reality. Mufti Shafi, Muarif-ul-Quran, Vol 1, 330.

${ }^{68}$ Maududi, Tafhim-ul-Quran, Vol. 5, 84.

${ }^{69}$ Maududi, Islami Riyasat, 531.

70 Syed Abul'ala Maududi, ed. Tarjumn-ul-Quran: Uloom Qurani wa Haqaiq Furqani ka zakheera, July 1948 ,Vol. 31 No. 3 (Lahore: Tarjuman-ul-Quran, 1948), 45.

${ }^{71}$ Ibid.

72 Ibid., 47.

73 Ibid., 48.

74 Ibid., 51.

75 Ibid., 52.

${ }^{76}$ Ibid., 55.

77 Ibid., 59.

78 Ibid., 60.

79 Abul'ala Maududi, ed., Tarjuman-ul-Quran:Ulum Qurani wa Haqaiq Furqani Ka Zakheera, Vol. 31, No 4. (Lahore: Taarjuman-ul-Quran, 1948) 44.

80 After the partition the government of West Punjab added an oath to the condition of employment in which each employee was asked to take oath of allegiance to the constitution of Pakistan which at that time was aimed for the Indian Act of 1935. Interestingly, Jamat-i-Islami forbade its followers and in general all Muslims no to take that oath because according to JI it was an un-Islamic Constitution. For Details see Monthly Tarjuman-ul-Quran Vol. 32, No. 2. (June 1948), 60.

${ }^{81}$ Abul'ala Maududi, Tarjuman-ul-Quran, Vol. 31, No. 3, 45.

${ }^{82}$ Qasmi, Khutbat wa Maktubat-i-Usmani, 88.

${ }^{83}$ Ibid., 93.

${ }^{84}$ Ibid., 98.

${ }^{85}$ Ibid., 102. 